\title{
Российская наука: территориальные проблемы развития
}

\author{
Ю.П.Бочаров, ЦНИИП Минстроя России, Москва \\ Н.Р.Фрезинская, ОНИР ГИПРОНИИ РАН, ЦНИИП Минстроя России, Москва \\ К.И.Сергеев, ОНИР ГИПРОНИИ РАН, МосКва
}

В статье рассматриваются проблемы пространственной организации исследовательской деятельности в нашей стране. Отмечается неравномерность территориального распределения объектов науки, которая усилилась за последние годы в процессе падения средних темпов роста экономики в пять раз по сравнению с ключевыми задачами Стратегии-2020. Анализируется главная зона научных исследований, образующая стержень социально-экономического развития России. На основе многофакторного регрессионного анализа определяются города, способные стать ведущими научными центрами этой зоны. В западной части страны численность населения такого города должна превышать 700 тыс. жителей, в восточной части - 500 тыс. жителей. Даётся оценка положительным изменениям, которые станут результатом строительства новых научно-образовательных центров в Кузбассе, Нижегородской, Тюменской и Белгородской областях, в Пермском крае (в соответствии с национальным проектом «Наука»).

Анализируется Столичный регион, включающий крупнейшую в стране групповую систему населённых мест. Характеризуются условия размещения объектов науки в ядре групповой системы и в её периферийной зоне. Рассматривается объединение на единой площадке подразделений Национального космического центра, создаваемого в Филях. Ожидается, что оно обеспечит повышение эффективности производственных, конструкторских и научно-исследовательских работ. Рассматривается перебазирование группы московских институтов в связи с необоснованным изъятием их земельных участков. Это обусловлено интересами рыночных структур и недостаточной заинтересованностью Минобрнауки в создании условий, способствующих производительному труду учёных. Выдвигается предложение по разработке для Столичного региона Отраслевой схемы территориального планирования исследовательской деятельности*).

Ключевые слова: объекты науки, города - научные центры, российская территория, регионы, крупные города, групповые системы населённых мест.

Science in Russia: Territorial Problems of Development

Yu.P.Bocharov, TsNIIP Minstroy of Russia, Moscow

N.R.Frezinskaya, ONIR GIPRONII RAS, TsNIIP Minstroy of Russia, Moscow

K.I.Sergeev, ONIR GIPRONII RAS, Moscow

The article considers the problems of spatial organization of research in our country. The unevenness of the territorial distribution of objects of science is noted, which has intensified in recent years in the process of a fall in the average economic growth rate by 5 times compared with the key objectives of Strategy 2020. The prospects of developing a zone of scientific research, which forms the core of the country's socio-economic development, are revealed. Based on multivariate regression analysis, cities are identified that can become the leading scientific centers of this zone. In the western part of the country, their population should exceed 700 thousand inhabitants, in the eastern part - 500 thousand inhabitants. The positive changes that will result from the construction of new research and educational centers in the Kuzbass, Nizhny Novgorod, Tyumen and Belgorod regions, in the Perm Territory (in accordance with the national project "Science") are evaluated.

The capital region is analyzed, which includes the country's largest group system of populated areas. The conditions of the placement of objects of science in the core of the group system and its peripheral zone are characterized. The unification of the units of the National Space Center, created in Fili, is under consideration. It is expected that it will provide increased efficiency in production, design and research.

Relocation of a group of Moscow institutes of the Russian Academy of Sciences in connection with the arbitrary withdrawal of their land plots is considered. This is due to the interests of market structures and the insufficient interest of the Ministry of Education and Science in creating conditions conducive to the productive work of scientists. A proposal is being put forward for developing a sectoral scheme for the territorial planning of research activities for the Capital Region.

Keywords: objects of science, cities - scientific centers, territory of Russia, regions, big cities, group systems of populated areas.

Пространственная организация исследовательской деятельности влияет на её эффективность и привлекает внимание градостроителей-науковедов. Качество пространственной организации важно рассматривать применительно к задачам территориального планирования, изучая объекты науки, сложившиеся в системах расселения России, и учитывая опыт зарубежных стран при размещении научных центров. Анализ, положенный в основу статьи, опирается на материалы ОНИР ГИПРОНИИ РАН,

*) Исследование выполнено за счет средств Государственной программы РФ «Развитие науки и технологий» на 2013-2020 гг. в рамках Плана фундаментальных научных исследований Минстроя России и РААСН на 2020 г. Тема 4.2.4. 
ЦНИИП Минстроя РФ, ГИПРОГОРа, НИиПИ генплана МО и ряда других организаций, которые решают градостроительные проблемы, возникающие в зонах концентрации учёных.

В 1991 году Россия получила от СССР примерно половину научных учреждений (в том числе 1,8 тыс. НИИ и 0,5 тыс. вузов), а также $70 \%$ учёных, выполнявших 79\% всех научноисследовательских работ. Переход к рыночной экономике позволял преодолевать кризисные явления, характерные для позднего советского времени, и увеличивать объёмы исследований, способствующих решению сложных проблем, стоящих перед страной. Сегодня приходится признать, что открывшиеся возможности используются далеко не полностью.

Процесс развития науки противоречив. С одной стороны, создаются новые и расширяются сложившиеся научные и научно-образовательные инновационные центры (например, в Москве на Воробьёвых горах, в Филях и Сколкове; в Новосибирске на берегах 0би; во Владивостоке на острове Русский). Количество передовых производственных технологий увеличивается (с начала века оно возросло почти в два раза). ( другой стороны, примерно на треть сократилась численность занятых исследованиями и разработками. Внутренние затраты (в процентах к ВВП) выросли до 1,1\%; тем не менее Россия существенно отстаёт от ведущих стран мира, занимая по данному показателю 35 место, вслед за Бразилией ${ }^{1}$.

Россия лидирует по площади территории, составляющей 17 125,2 тыс. кв. км. На одного занятого исследованиями и разработками здесь приходится 24,2 кв. км. Тем не менее в стране, располагающей такими территориальными ресурсами, пространственное развитие исследовательской деятельности меняет своё направление. На первый план вышла тенденция центростремительного развития, противопоставленная равномерному и пропорциональному освоению территории, характерному для СССР. Идёт чрезмерное развитие столицы за счёт ослабления удалённых от неё регионов. Из 13 наукоградов, работающих в России, восемь развиваются на базе Москвы ${ }^{2}$. По внутренним затратам на исследования и разработки первое место занимает столичный регион - на него приходится 43,9\% этих затрат. Чтобы получить для США соизмеримый показатель, необходимо суммировать данные по пяти штатам. На Калифорнию, Массачусетс, Техас, Нью-Йорк и Мэриленд приходится 44,4\% затрат на исследования и разработки. Несколько десятилетий назад Нью-Йорк на восточном побережье был первым по этому показателю. Сегодня его место заняла Калифорния на западном побережье ${ }^{3}$.
Продолжается существенное отставание России по расходам на науку от других ведущих держав. Если в 2017 году мы отставали от США по объёму государственных расходов на науку в 28 раз, то в 2019-ом отстали уже в 33 раза. От Китая отставали в 18 раз, а в 2019-ом уже в 22 раза. 0т Германии отстаём в восемь раз. Благодаря поддержке науки и грамотной коммерциализации разработок в США высокотехнологичная компьютерная корпорация «Эппл» (Apple) в 2018 году первой в мире преодолела уровень капитализации в триллион долларов, что вдвое больше, чем у всех российских компаний. Одной из главных причин является недостаточное финансирование научных исследований в России. Хотя в проекте федерального бюджета на 2020 год предусмотрено некоторое увеличение расходов на науку, до сих пор не выполнен майский указ Президента РФ 2012 года, в соответствии с которым уровень расходов на науку должен составлять 1,77\% ВВП [1].

0беспечение связи науки с высшим образованием и производством в нашей стране затрудняется отсутствием комплексного подхода к развитию отраслей, в первую очередь ответственных за научно-технологический прогресс. За Уралом, в Сибирском и Дальневосточном федеральных округах, занимающих две трети территории России и концентрирующих менее пятой части российского населения, сосредоточивается $16,7 \%$ студентов образовательных организаций высшего образования (ООВО) и только 9,4\% занятых исследованиями и разработками. Объём отгруженных товаров, работ и услуг для обрабатывающего производства составляет 11,9\%, для добывающего производства (наименее наукоёмкого) - 28,6\%. Таким образом, запад страны лидирует в области науки и высшего образования, в то время как восток вносит существенный вклад в добычу полезных ископаемых ${ }^{4}$.

Выход из сложившейся ситуации нередко видят в совершенствовании информационно-коммуникационных технологий (ИКТ). В наши дни они получают широкое распространение, способствуя модернизации экономики и повышению численности работающих на удалении от своего офиса, лаборатории или университета. В США (по данным «Global Workplace Analytics») в 2015 году 3,9 млн чел. (или 2,9\% экономически активного населения ${ }^{5}$ ) трудились дистанционно по меньшей мере половину рабочего времени, и это вдвое больше, чем десять лет назад. В области производства и образовательных услуг доля работающих дистанционно составляла соответственно 8,5 и 7,5\%. Наиболее высока эта доля в области научных исследований, профессиональных и технических услуг - 17\% [2].

\footnotetext{
${ }^{1}$ Данные федерального статистического наблюдения по форме № 2-наука «Сведения о выполнении научных исследований и разработок»; зарубежные страны - базы данных ОЭСР (OECD.Stat), ЮНЕСКО (UIS.Stat), Евростата. Расчеты ИСМИЭЗ НИУ ВШЭ (выполнены Татьяной Ратай) (issek.hse.ru)

${ }^{2}$ Наукограды Подмосковья: какие отрасли науки развивают учёные региона. 29 июня 2017 г. (mosreg.ru>sobytiya...news-submoscow/naukogrady...nauki).

${ }^{3}$ S\&E Indicators 2018/NSF- National Foundation (nsf.gov_sstatistics/2018/nsb20181/).

${ }^{4}$ Регионы России. Социально-экономические показатели. 2018: Р32 Стат. сб. / Росстат. - М., 2018. - 1162 c. ISBN 978-5-89476-458-0 (gks.ru>folder/210/ document/13204).

${ }^{5}$ В России соответствующий показатель к 2016 году достиг 4\%. Совершенствование ИкТ относят к числу приоритетных направлений развития науки, технологий и техники (затраты в 2017 году составляли 1487 628,6 млн руб.) (Там же).
} 
ИКТ дают возможность увидеть и услышать человека, находящегося на другом конце Земного шара, проводить дистанционные эксперименты, контактировать с представителями производства и образовательных организаций, устраивать заочные совещания, телеконференции и научные форумы и пользоваться услугами удалённых суперкомпьютеров. Создаются виртуальные лаборатории (virtuallaboratories) и системы распределённых вычислений (gridsystems). Исследовательская деятельность постепенно смещается в онлайновую среду; по свидетельству Е.3. Мирской, наблюдается устойчивая положительная корреляция между профессиональной продуктивностью учёных и использованием интернета ${ }^{6}$. Сегодня $66 \%$ учёных опираются на удалённые информационные базы, и в России эта цифра выше, чем в западных странах [3]. Обеспечивая научные коммуникации, ИКТ помогают преодолевать расстояния и включать в сферу развития науки удалённые территории страны.

Личные контакты гарантируют незамедлительность реакций при столкновении различных мнений, мобилизуют творческие способности и содействуют генерации новых идей. Должно быть, поэтому они и не подвержены действию времени. М.В. Ломоносов вспоминал, как «часто требует астроном механикова и физикова совета, ботаник и астроном - химикова...» [4]. Ломоносову вторят современные организаторы науки: они подчёркивают необходимость непосредственного рабочего взаимодействия учёных с представителями производства и образования. Неслучайно московское «Сколково» создаёт свои филиалы в Челябинске, Владивостоке, Екатеринбурге, Новосибирске, СанктПетербурге и Казани, а ректор Финансового университета при правительстве РФ М. Эскиндаров отстаивает преимущества очной формы обучения: «...интернет-лекции не смогут дать того объёма знаний, компетенций и умений, который студент получает в классической форме обучения» $[5 ; 6]$.

Совершенствование ИКТ является важной, но не единственной предпосылкой движения России по пути научнотехнологического прогресса. Проблема равномерного и пропорционального развития страны не теряет актуальности. Применительно к исследовательской деятельности речь идёт о филиации - процессе создания дочерних научных центров, опирающихся на материнские научные центры, о превращении очагов развития науки в базу для создания новых очагов в глубинных и периферийных частях России. Контуры этой стратегии были намечены академиком Б.М. Кедровым и его соавторами ещё в 1969 году [7].

Пути пространственной организации исследовательской деятельности подсказывает сама практика. В странах, которые занимают первые места по уровню научно-технологического развития и располагают значительными территориальными ресурсами, возникают главные зоны научных исследований.

\footnotetext{
${ }^{6}$ Научные коммуникации : Лекция. Санкт-Петербургский государствен ный университет культуры и искусств (studfile.netspreview/3191866/page:8/).
}

В США сложились две зоны: одна разместилась на побережье Атлантического океана (с научными центрами на базе НьюЙорка, Бостона, Вашингтона и Филадельфии), другая - на побережье Тихого океана (с научными центрами на базе Сан-Франциско, Лос-Анджелеса и Сан-Диего). В КНР зона сложилась на востоке страны (с научными центрами на базе Пекина, Тяньцзина, Шанхая и Гуанчжоу).

Главная зона научных исследований (занимающая пятую часть территории России) протянулась от западной государственной границы до восточной. В общих чертах она совпадает с зоной активной инновационной деятельности, опирающейся на южный широтный экономический пояс, который сложился вдоль Транссиба [8]. Наука возглавляет процесс производства и распространения инноваций, и на территории главной зоны наряду с научными учреждениями, университетами и научными центрами размещаются технопарки, инкубаторы инноваций, бизнес-центры, инженерные центры, высокотехнологичные предприятия и другие объекты, занятые внедрением результатов труда учёных. Создаётся стержень социально-экономического развития России, образующий ответвления в сторону малоосвоенных территорий, вовлекая их тем самым в инновационный процесс.

Требует решения вопрос о размерах городов, способных возглавить главную зону. В ходе многофакторного регрессионного анализа изучены характеристики градостроительной среды российских регионов. Рассмотрены связи между численностью занятых в исследованиях и разработках (функция) и характеристиками среды (аргументы). Установлено, что наибольшее влияние на развитие науки оказывает размер города - регионального центра. Причиной является ёмкость этого показателя, его способность служить косвенным отражением качества среды жизнедеятельности, её инвестиционной привлекательности и, что в данном случае особенно важно, - способность представлять в обобщённом виде группу характеристик, тесно связанных с характеристиками исследовательской деятельности. В их числе: 1) численность занятых в обрабатывающей промышленности; 2) численность студентов образовательных организаций высшего образования; 3) затраты на информационно-коммуникационные технологии; 4) численность городского населения региона. Между численностью населения городов - региональных центров, и перечисленными характеристиками обнаруживаются тесные связи: $0,82 \leqslant r \leqslant 0,98$, где $r$ - коэффициент корреляции.

Вырастая до 700 тыс. жителей, город преодолевает рубеж, с которым связано «созревание» среды и сохранение тех её качеств, которые способствуют выполнению исследований и разработок. Речь идёт о наличии устойчивых связей науки с градостроительной средой - они позволяют составить представление об уровне развития науки, опираясь на численность городского населения.

Выбирая города, способные стать ведущими научными центрами, необходимо учитывать особенности западной и восточной России. Для востока страны пороговые значения 
численности населения могут быть снижены до 500 тыс. человек. Это потребует вложения больших денежных средств, разработки программы совершенствования градостроительной среды и создания условий, благоприятствующих повышению эффективности исследовательской деятельности. Вместе с тем это позволит активизировать процесс инновационного развития территорий, удалённых от традиционных очагов концентрации учёных. Ориентируясь на пороговые значения численности населения, важно учитывать реальную обстановку, сложившуюся в каждом городе. Например, Тольятти с населением 707 тыс. чел., находящийся в Приволжском федеральном округе, и Новокузнецк с населением 553 тыс. чел., находящийся в Сибирском федеральном округе, являются городами, неспособными в настоящее время служить опорными базами развития науки [9].

Ведущими научными центрами главной зоны научных исследований могут быть: Москва, Санкт-Петербург, Новосибирск, Екатеринбург, Нижний Новгород, Казань, Челябинск, Омск, Самара, Ростов-на-Дону, Уфа, Красноярск, Пермь, Воронеж, Волгоград, Краснодар, Саратов, Тюмень, Томск, Кемерово, Иркутск, Хабаровск и Владивосток. Размещением перечисленных городов определяется схема генеральных осей научно-технологического развития России. На осях фиксируются исходные точки возможных ответвлений. Например, от Санкт-Петербурга к Архангельску и Мурманску; от Ростова-на-Дону к Симферополю и Севастополю; от Тюмени к Ханты-Мансийску; от Иркутску к Якутску; от Владивостока к Южно-Сахалинску, Магадану и Петропавловску-Камчатскому (рис. 1).

В Послании Президента РФ Федеральному собранию говорится о необходимости мощного технологического развития страны, которое будет обеспечено строительством в российских регионах 15-и научно-образовательных центров ${ }^{7}$. Создаваемые в рамках национального проекта «Наука», они

7 Послание Президента Федеральному собранию (http://www.kremlin. ru/events/president/transcripts/messages/59863).

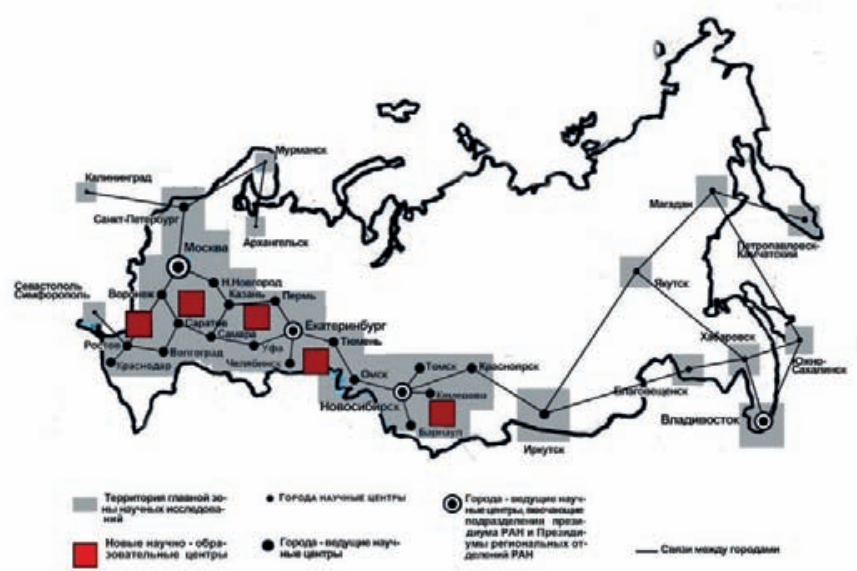

Рис. 1. Главная зона научных исследований на территории Poccuu должны объединить ведущие университеты и научные организации с компаниями, которые действуют в реальном секторе экономики. На совещании, состоявшемся у премьер-министра в мае 2019 года, были названы адреса первых пяти центров: Кузбасс, Нижегородская, Тюменская и Белгородская области, Пермский край ${ }^{8}$.

На их территориях будет проводиться широкий круг научно-исследовательских и опытно-конструкторских работ в области сельского хозяйства, энергетики, машиностроения, химических и ядерных технологий, а также в области биологической безопасности животных, растений и человека. Одновременно будет осуществляться подготовка кадров. Учитывается, что деятельность создаваемых центров выйдет за пределы районов их размещения. Например, в состав научнообразовательного центра Тюмени будут включены предприятия и организации, которые располагаются на территории Ханты-Мансийского и Ямало-Ненецкого автономных округов. К 2021 году будет сформировано ещё десять центров. Желательно, чтобы часть этих центров разместилась на территории главной зоны научных исследований, восточнее Кузбасса.

По данным Росстата (на 2017 год) в Столичном регионе, занимающим 46,9 тыс. кв. км (менее 0,3\% территории страны), сосредоточивается $13,6 \%$ российского населения. Плотность населения региона - 426 чел/кв. км. По доле занятых с высшим образованием (47,4\%) и численности студентов 0ОВ0 (396 чел. на 10000 чел. населения) регион более чем на треть превышает средние показатели по России. А по затратам на информационные и коммуникационные технологии - почти в пять раз. На территории столицы сосредоточены штаб-квартиры крупнейших госкомпаний, частных компаний и других учреждений, пополняющих столичный бюджет. Наряду с московскими, налоги платят компании, работающие в других регионах страны, но юридически приписанные к Москве (в структуре её промышленного производства $20 \%$ составляет добыча нефти и газа). Объём отгруженных товаров, выполненных работ и услуг - 395,7 тыс. рублей на душу населения (по обрабатывающему производству). На регион приходится 17\% всех инвестиций в основной капитал - 132,0 тыс. руб. на душу населения ${ }^{9}$

Социально-экономическая среда Столичного региона смягчает воздействие негативных и усиливает воздействие позитивных факторов развития науки. В период между 2005 и 2017 годами падение численности занятых в исследованиях и разработках составляло 8,4\% (при 13,0\% по России в целом). Численность докторов наук увеличилось на 4,3\%, количество патентов на изобретения и полезные модели - на 10,4, а количество разработанных передовых производственных

${ }^{8} 0$ развитии научно-производственной кооперации. Совещание с вицепремьерами. Вступительное слово Дмитрия Медведева. 13 мая 2019 г. Горки, Московская область (http://government.ru/news/36624/).

9 Регионы России. Социально-экономические показатели. 2018 : Р32. - М. : Росстат, 2018. - 1162 c. ISBN 978-5-89476-458-0 (gks.ru>folder/210/ document/13204). 
технологий - на 96,8\%. В 2012-2016 годы московскими исследователями была опубликована 71 тыс. статей, индексируемых в базе данных «Web of Science» (46\% от числа статей, приходящихся на Россию). Исследователями, работающими в Московской области - 16 тыс. статей (10\%). Доля Столичного региона составила $56 \%$, что значительно превышает долю региона в численности занятых исследованиями и разработками на протяжении того же периода времени ${ }^{10}$.

В составе Столичного региона развивается крупнейшая в стране групповая система населённых мест. Ядро системы занимает Москва; в периферийной зоне разместились 74 города, окружающих столицу. Для работы объектов науки в разных зонах системы обеспечиваются неодинаковые условия. Размещение в составе ядра требует больших денежных затрат на формирование и реконструкцию материальной среды исследовательской деятельности. Оно обеспечивает разнообразие профессиональных и внепрофессиональных контактов, позволяет пополнять исследовательские коллективы квалифицированными сотрудниками, создавать центры компетенции и участвовать в работе образовательных учреждений, развивать интенсивные связи с представителями производственных предприятий и при этом гарантирует высокое качество среды обитания. Размещение в составе периферийной зоны позволяет экономить денежные средства благодаря низкой (по сравнению с крупным городом) стоимости земельных участков, зданий и сооружений. На территории периферийной зоны могут быть созданы землеёмкие объекты, организованы обширные санитарно-защитные разрывы, а зоны расселения исследователей расположены в благоприятных природных условиях.

В 1980 году нами изучались сети объектов науки в городских агломерациях - системах населённых мест различного размера, развивающихся на базе крупных городов. Определялись базовые индексы агломеративности, отражающие долю периферийной зоны каждой системы в суммарной численности кадров научных учреждений. Как было установлено, при населении ядра, превышающем 1 млн жителей, и сети объектов науки, сложившейся в границах системы и включавшей более десяти объектов, размеры индексов колебались в пределах от 10 до 20\%. Предположено, что в перспективе базовые индексы могут существенно возрасти [10].

Результаты анализа интересно сравнить с теми, которые были получены в 2019 году. Московская групповая система рассматривалась в качестве крупнейшей городской агломерации. Речь шла о сопоставлении наиболее общих тенденций развития ядра и периферийной зоны - детальный анализ

${ }^{10}$ Расчеты ИСИЭЗ НИУ ВШЭ по данным WebofScienceCoreCollection (SCIEXPANDED, SSCI, A\&HCI) от 18.05.2017 г.; результаты проекта «Разработка теоретических и методических подходов к исследованию активности субъектов инновационного процесса» Программы фундаментальных исследований НИУ ВШэ. Материал подготовила Е. Л. Дьяченко (Интернет-сайт ИСИЭЗ НИУ ВШЭ - http://issek.hse.ru). был затруднён изменением методики расчёта численности научных кадров ${ }^{11}$. Установлено, что в период между 1995 и 2017 годами доля Московской области в численности занятых исследованиями и разработками увеличилась с 24,6 до 27,8\%, что соответствовало прогнозу изменения индексов агломеративности. Тем не менее картина развития исследо-

${ }^{11}$ В 1980-х годах действовал Общесоюзный классификатор отраслей народного хозяйства (ОКОНХ), а в 2010-х годах - Общероссийский классификатор видов экономической деятельности (ОКВЭД).

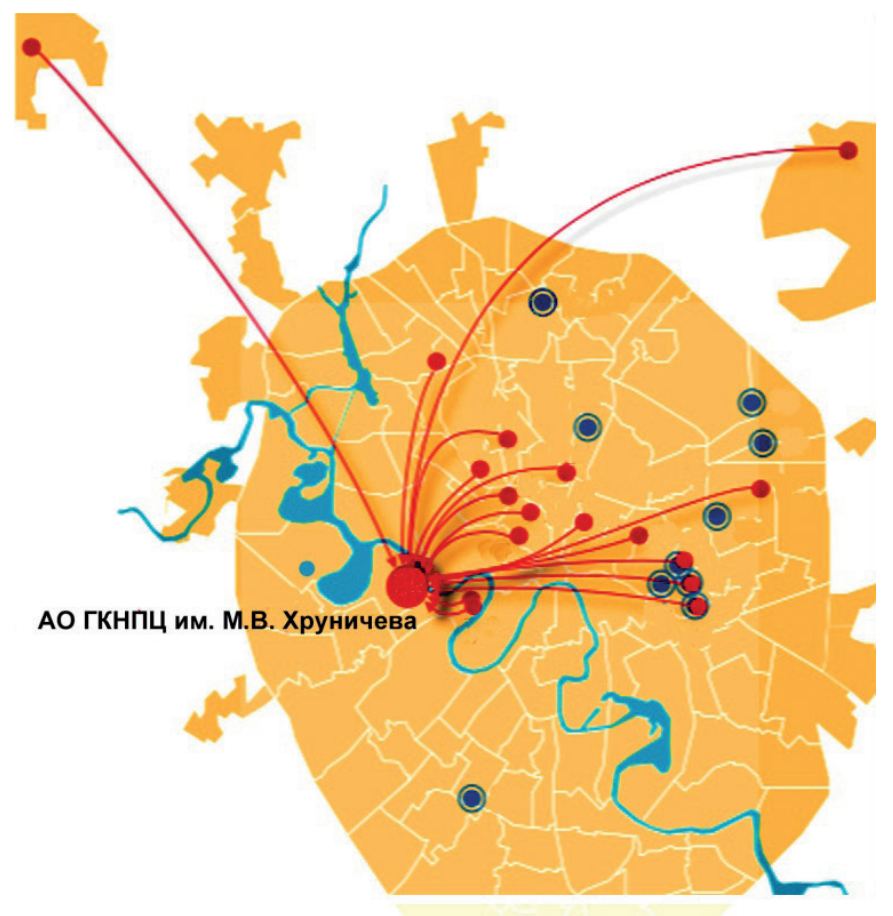

\section{ОРГАНИЗАЦИИ ГОСКОРПОРАЦИИ "РОСКОСМОС", ПЛАНИРУЕМЫЕ К ПЕРЕМЕЩЕНИЮ НА МОСКОВ- СКУЮ ПЛОЩАДКУ В ФИЛЯХ \\ ОРГАНИЗАЦИИ, ПЕРЕМЕЩЕНИЕ КОТОРЫХ НЕ- ЦЕЛЕСООБРАЗНО}

Рис. 2. Перемещение подразделений «Роскосмоса» на площадку Национального космического центра в Москве (изображение из открытых источников сети Интернет)

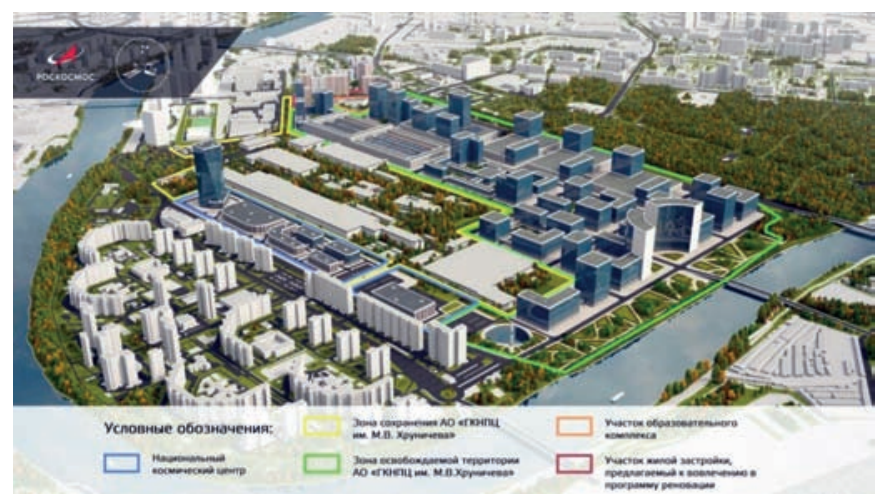

Рис. 3. Национальный космический центр в Москве. Макет (изображение из открытых источников сети Интернет) 
вательской деятельности оказалась значительно сложнее той, из которой исходил прогноз 40-летней давности (в 1980 году не подвергалось сомнению, что численность кадров научных учреждений с годами будет увеличиваться).

В ходе развития Московской системы концентрация объектов науки в ядре системы сопровождается деконцентрацией (переносом на территорию периферийной зоны). Концентрация идёт, например, при создании Национального космического центра (НКЦ) в Филях, недалеко от Кутузовского проспекта, на землях ГКНПЦ им. М.В. Хруничева ${ }^{12}$. Происходит «стягивание» на площадку нового центра 17-ти подразделений «Роскосмоса», часть которых переезжает из удалённых районов Москвы и Мо-
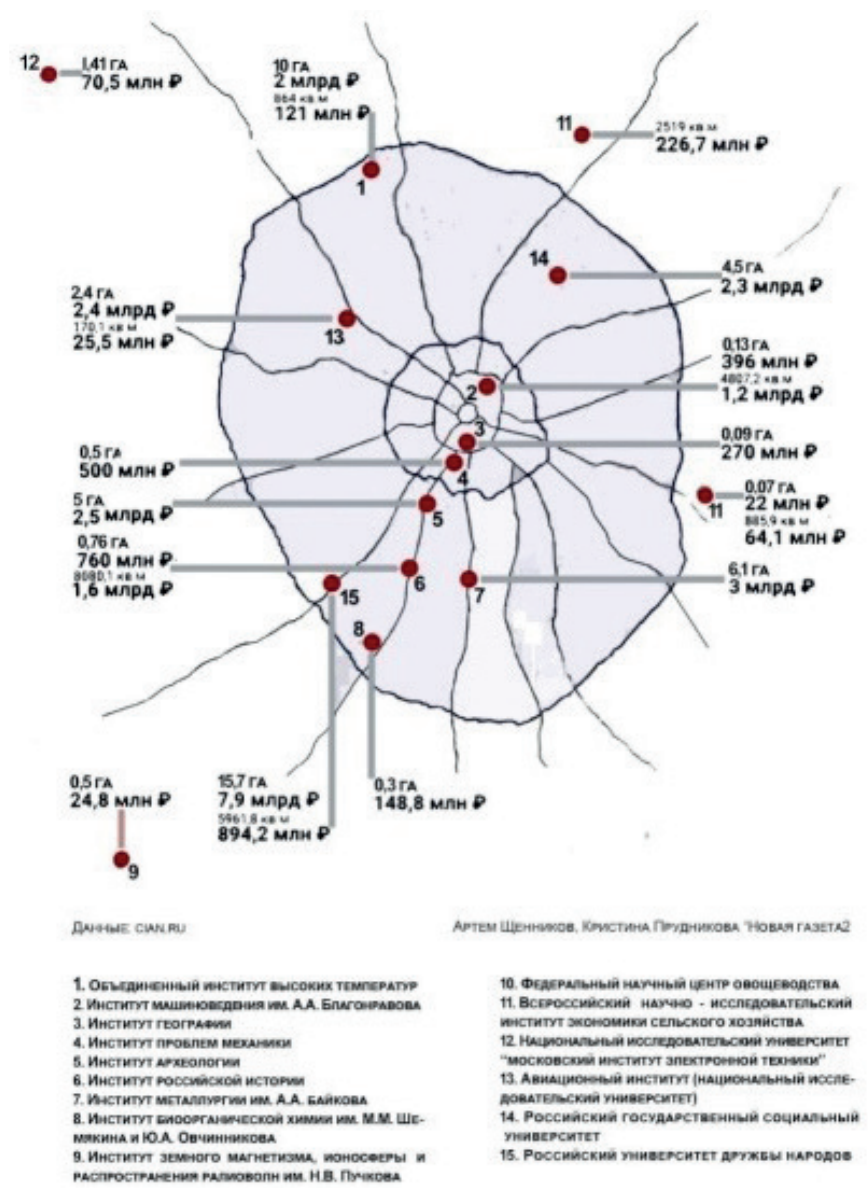

Рис. 4. Вынос объектов московской науки с изъятием зданий и земельных участков [11]

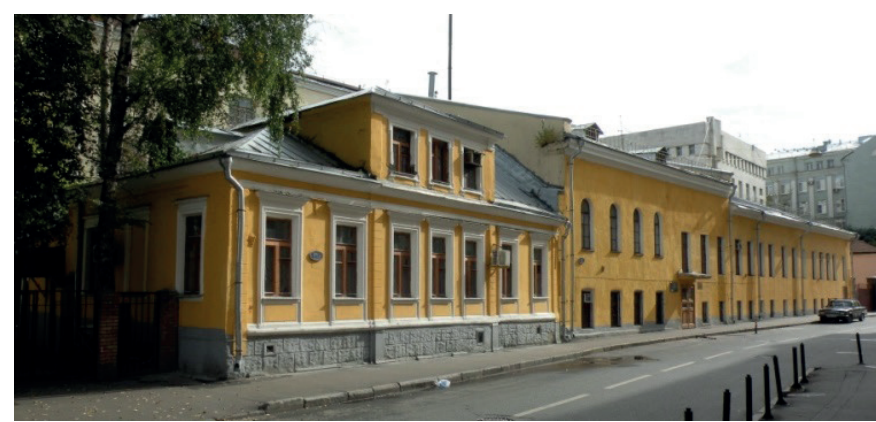

Pис. 5. Институт географии РАН. Москва, Старомонетный переулок (фото из открытых источников интернета) сковской области. Численность сотрудников, сосредоточенных сегодня на этой площадке, составляет восемь тысяч человек; она увеличится до 20 тыс. человек к концу расчётного срока. Аэрокосмический кластер будет включать головные подразделения организаций ракетно-космической отрасли, конструкторские бюро, профильные структурные подразделения научно-исследовательских и образовательных организаций. На территории, занятой заброшенными заводскими корпусами, предполагается построить здания и сооружения, общая площадь которых составит 2,89 млн кв. м (для сравнения: площадь зданий и сооружений Москва-Сити - 2,5 млн кв. м) (рис. 2).

Московская мэрия внесёт 25 млрд руб. в уставной капитал «Мосинжпроекта» (компании, которая будет застраивать территорию), а государственная корпорация «Роскосмос» предоставит земельный участок (90 га). Впоследствии «Роскосмос» рассчитывает получить деньги за продажу 30 га земли, освобождаемой в ходе переезда в НКЦ своих подразделений, а также сэкономить значительные средства в результате компактного размещения сотрудников на меньших площадях. Долги ГКНПЦ им. М.В. Хруничева сегодня составляют около двух миллиардов рублей. Ожидается, что создание на его участке Национального космического центра позволит повысить эффективность производственных, конструкторских и научно-исследовательских работ (рис. 3).

Деконцентрация объектов науки сопровождается изъятием территорий у обширной группы объектов, расположенных в столице. Причиной выноса является развитие Москва-Сити. В этом деловом центре будет размещён ряд министерств и ведомств; в 2018 году Минэкономики, Минпромторга, Минкомсвязи, Росстандарт, Росимущество и Ростуризм уже переехали в новые помещения. Агентом сделки является компания «Дом.РФ», которым приобретены офисные помещения площадью 75 тыс. кв. м и стоимостью 35 млрд рублей. Продажа освобождаемых министерствами 180 тыс. кв.м не позволит полностью компенсировать затраты. Расплачиваться соглашается Минобрнауки, предложившее ряду своих институтов освободить занимаемые участки вместе с расположенными на них зданиями. Хотя продолжал ещё действовать мораторий на отчуждение имущества РАН [11] (рис. 4).

Среди выселяемых - Институт географии РАН, одно из старейших научных учреждений Москвы. Институт размещается в центре города в Старомонетном переулке, в составе «Замоскворечья» - сложившегося комплекса научных учреждений, в зданиях, образующих объект культурного наследия. Здесь, в Старомонетном переулке сосредоточены лаборатории, конференц-зал, библиотека и музей. Ведутся фундаментальные и прикладные исследования, не требующие организации санитарно-защитных разрывов. Тем не менее планируется

12 Принято решение построить Национальный космический центр в Москве на месте ГКНПЦ им. Хруничева (http://habr.com>news/t/457662/); В Москве приступили к созданию Национального космического центра (https://stroi.mos.ru/news/v-moskvie-nachalos-sozdaniie-natsional-noghokosmichieskogho-tsientra?from $=\mathrm{cl}$ ). 
перемещение института в неизвестном направлении и передача его участка стоимостью 270 млн руб. агентству «Дом.РФ». Это негативно скажется на эффективности ведущихся научных работ. По ряду показателей Институт географии входит в число учреждений, лидирующих в своей области знаний. Его сотрудники публикуют ежегодно по 15-20 монографий и до 400 научных статей (рис. 5).

В целом предполагается вынос научно-исследовательских институтов, образовательных организаций и их подразделений за пределы земельных участков, площадь которых составляет в сумме 48 га. Создаётся впечатление, что изменение рисунка сети объектов науки в Московской групповой системе населённых мест обусловлено интересами рыночных структур и недостаточной заинтересованностью Минобрнауки в создании условий, благоприятствующих производительному труду учёных. Не имеющие действенной государственной поддержки, институты и лаборатории могут лишиться возможности конкурировать с частными застройщиками, располагающими значительными финансовыми ресурсами. В борьбе функций на территории Московской системы населённых мест наука часто уступает свои позиции. Равнодействующая процессов концентрации и деконцентрации объектов науки направляется от ядра системы к её периферии. Этим объясняется повышение удельного веса области в численности занятых исследованиями и разработками.

$$
* * *
$$

Для столичного региона пора разработать Отраслевую схему территориального планирования, призванную определить пути пространственной организации исследовательской деятельности с учётом сложившейся градостроительной ситуации и всей совокупности факторов, воздействующих на процессы производства знаний. Важность стоящей задачи обусловлена необходимостью совершенствования крупнейшего исследовательского комплекса страны, а также ролью столицы в развитии отечественной науки. Москва координирует деятельность её объектов и должна нести ответственность за судьбу других российских городов - научных центров.

\section{Лuтература}

1. Волчкова, Н. Приметы перемен / Н. Волчкова // Научное сообщество. - 2019. - № 11 (219). - С. 12-17.

2. Дхаван, Э. Эффективность на расстоянии [Электронный ресурс] / Э. Дхаван, Т. Чаморро-Премузик // Harvard Business Review Россия. - Режим доступа: https://hbr-russia. ru/management/operatsionnoe-upravlenie/p26681 (дата обращения 10.01.2020).

3. Богданова, И.Ф. Онлайновое пространство научных коммуникаций // Социология науки и технологий. - 2010. - Том 1. - № 1. - С. 104-161. - Режим доступа: https://cyberleninka.ru/ article/n/onlaynovoe-prostranstvo-nauchnyh-kommunikatsiy-1/ viewer (дата обращения 25.08.2019).

4. Ломоносов, М.В. Записка о необходимости преобразования Академии Наук. 1758-1759 / М.В. Ломоносов //
Полное собрание сочинений в 11 томах; Т. 10. - М.-Л. : АН СССР, 1950-1983.

5. Бочаров, Ю.П. Градопреобразующая роль инновационной деятельности / Ю.П. Бочаров, Н.Р. Фрезинская, К.И. Сергеев // Academia. Архитектура и строительство. - 2019. - № 4. - C. 60-67.

6. Эскиндаров, М. Финансовый университет входит в число вузов, которые практически гарантируют трудоустройство выпускникам // «Review», тематическое приложение к журналу «Коммерсантъ». - 27.02.2019. - № 35.

7. Кедров, Б.М. Современная наука и проблемы организации научных центров / Б.М. Кедров, Ю.П. Бочаров, К.И. Сергеев // Архитектура СССР. - 1969. - № 1. - С. 3-11.

8. Фрезинская, Н.Р. Национальная инновационная система России: перспективы пространственной организации / Н.Р. Фрезинская // Градостроительство. - 2013. - № 4. - С. 32-40; № 5. - C. 8-14.

9. Любовный, В.Я. Монопрофильные города России: истоки, эволюция развития и регулирования / В.Я. Любовный. - М. : Экон-Информ, 2018. - 445 с. - С. 116-140. ISBN 978-5-907057-00-5

10. Метаньев, Д.А. Объекты науки и градостроительная среда / Д.А. Метаньев, Н.Р. Фрезинская, Л.Г. Анисимова // Известия всесоюзного географического общества. - Мартапрель 1980. Том 112, вып. 2. - С. 165-170.

11. Заякин, А. Науки офисы питают. Как правительство отнимает земли и здания у ученых в счет собственных долгов / А. Заякин, А. Щенников // Новая газета. - 30.09.2019. - № 109.

\section{References}

1. Volchkova N. Primety peremen [Signs of change]. In: Nauchnoe soobshchestvo [Scientific community], 2019, no. 11 (219), pp. 12-17.

2. Erika Dkhavan. Effektivnost' na rasstoyanii [Efficiency at a Distance]. In: Harvard Business Review Rossiya [Harvard Business Review Russia]. Access mode: https://hbr-russia.ru/management/ operatsionnoe-upravlenie/p26681 (accessed 01.10.2020).

3. Bogdanova I.F. Onlainovoe prostranstvo nauchnykh kommunikatsii [Online space of scientific communications]. In: Sotsiologiya nauki i tekhnologii [Sociology of Science and Technology], 2010, Vol. 1, no. 1, pp. 104-161. Access mode: https://cyberleninka.ru/article/n/onlaynovoe-prostranstvonauchnyh-kommunikatsiy-1/viewer (accessed 25.08.2019). (In Russ., abstr. in Engl.)

4. Lomonosov M.V.Zapiska o neobkhodimosti preobrazovaniya Akademii Nauk. 1758-1759 [Note on the need to transform the Academy of Sciences. 1758-1759]. Polnoe sobranie sochinenii $\checkmark 11$ tomakh [Complete works in 11 volumes], Vol. 10. MoscowLeningrad: AN SSSR, 1950-1983.

5. Bocharov Yu.P., Frezinskaya N.R., Sergeev K.I. Gradopreobrazuyushchaya rol' innovatsionnoi deyatel'nosti [The city-transforming role of innovative activity]. In: Academia. Arkhitektura i stroitel'stvo [Academia. Architecture and construction], 2019, no. 4, pp. 60-67. (In Russ., abstr. in Engl.) 
6. Eskindarov M. Finansovyi universitet vkhodit $v$ chislo vuzov, kotorye prakticheski garantiruyut trudoustroistvo vypusknikam [Financial University is one of the universities that practically guarantee employment for graduates]. In: "Review", tematicheskoe prilozhenie k zhurnalu "Kommersant" [ "Review", thematic supplement to the magazine "Kommersant"], 27.02.2019, no. 35 .

7. Kedrov, B.M. Bocharov Yu.P., Sergeev K.I. Sovremennaya nauka i problemy organizatsii nauchnykh tsentrov [Modern science and problems of organizing scientific centers]. In: Arkhitektura SSSR [Architecture of the USSR], 1969, no. 1, pp. 3-11.

8. Frezinskaya, N.R. Natsional'naya innovatsionnaya sistema Rossii: perspektivy prostranstvennoi organizatsii [National innovation system of Russia: perspectives of spatial organization]. In: Gradostroitel'stvo [Urban planning], 2013, no. 4, pp. 32-40; no. 5, pp. 8-14. (In Russ., abstr. in Engl.)
9. Lyubovnyi V.Ya. Monoprofil'nye goroda Rossii: istoki, evolyutsiya razvitiya i regulirovaniya [Monoprofile cities of Russia: origins, evolution of development and regulation]. Moscow, Ekon-Inform Publ., 20186445 p pp. 116-140. ISBN 978-5-907057-00-5

10. Metan'ev D.A., Frezinskaya N.R., Anisimova L.G. Ob"ekty nauki i gradostroitel'naya sreda [Objects of science and urban planning environment]. In: Izvestiya vsesoyuznogo geograficheskogo obshchestva [News of the All-Union Geographical Society], 1980, Vol. 112, Iss. 2, pp. 165-170. (In Russ.)

11. Zayakin A., Shchennikov A. Nauki ofisy pitayut. Kak pravitel'stvo otnimaet zemli i zdaniya u uchenykh $v$ schet sobstvennykh dolgov [Science feeds offices. How the government takes away land and buildings from scientists at the expense of its own debts]. In: Novaya gazeta, 09.30.2019, no. 109.

Бочаров Юрий Петрович (Москва). Доктор архитектуры, профессор, академик РААСН. Главный научный сотрудник ФГБУ ЦНИИП Минстроя России (Москва, пр. Вернадского, 29. ЦНИИП Минстроя России). Эл.почта: albocharova28@gmail.com.

Фрезинская Наталия Рахмиэлевна (Москва). Доктор архитектуры, советник РААСН. Ведущий научный сотрудник Отделения научно-исследовательских работ ФГБУН «ОНИР ГИПРОНИИ РАН» (117971, Москва, ул. Губкина, д. 3. ОНИР ГИПРОНИИ РАН), главный научный сотрудник ЦНИИП Минстроя России (Москва, пр. Вернадского, 29. ЦНИИП Минстроя России). Эл.почта: mafre@list.ru.

Сергеев Кирилл Игоревич (Москва). Кандидат архитектуры, советник РААСН. Заместитель директора по научной работе ФГБУН «ОНИР ГИПРОНИИ РАН» (117971, Москва, ул. Губкина, д. 3. ОНИР ГИПРОНИИ РАН). Эл.почта: kser3333@yandex.ru.

Bocharov Yuri P. (Moscow). Doctor of Architecture, Professor, Academician of RAACS. Chief Researcher of the Central Institute for Research and Design of the Ministry of Construction and Housing and Communal Services of the Russian Federation (29 Vernadskogo avenue, Moscow, 119331. TsNIIP Minstroy of Russia). E-mail: albo-charova28@gmail.com.

Frezinskaya Nataliya R. (Moscow). Senior Researcher at the Department of research works of the GIPRONII RAS (3 Gubkina st., Moscow, 117971. ONIR GIPRONII RAS), Chief Researcher of the Central Institute for Research and Design of the Ministry of Construction and Housing and Communal Services of the Russian Federation (29 Vernad-skogo avenue, Moscow, 119331. TsNIIP Minstroy of Russia).E-mail: mafre@list.ru.

Sergeyev Kirill I. (Moscow). Candidate of Architecture, Advisor of RAACS. Deputy Director for Research at the Department of research works of the GIPRONII RAS (3 Gubkina st., Moscow, 117971. 0NIR GIPRONII RAS). E-mail: kser3333@yandex.ru. 